\title{
The ambiguity of Johan Heyns: Sitting at Bavinck's left or right hand?
}

\begin{abstract}
Following some biographic introductory comments, the argument of this contribution proceeds in two steps. First, the distinction between Herman Bavinck's left and right hand is clarified, amongst others with reference to the distinction between fides qua and fides quae, and illustrated with examples from the subsequent reformed tradition. Second, an analysis of Heyns' own related theological choices is offered on this basis.
\end{abstract}

\section{INTRODUCTION}

This contribution emerges from personal considerations that call for clarification. In 2008 I worked at the Centre of Theological Inquiry in Princeton on a project on Abraham Kuyper's understanding of the relationship between creation and salvation. In the process I grappled with the reception of Kuyper in South Africa and the stark contrast between the followers of Kuyper and the followers of Karl Barth in reformed circles amidst the struggle against apartheid and apartheid theology at least up to 1990. Despite the disastrous reception of Kuyper in South Africa, my intuition was that his understanding of the relationship between creation and salvation is more attractive for ecological theology than that of Barth (see Conradie 2011).

In the process of reading Kuyper's rather journalistic contributions to theology I rediscovered Herman Bavinck's far more sophisticated writings. I was deeply impressed. However, the Bavinck that I discovered for myself, the one of The Philosophy of Revelation (1909), the one who wrote so eloquently about nature and grace (see Veenhof 2006) was not quite the Bavinck that I knew from my formative training at Stellenbosch. I then remembered a comment that I once heard from Willie Jonker, namely that he regarded his own approach to reformed theology as very much in line with the theology of Kuyper and Bavinck. I also knew that Jonker was of course deeply influenced by Barth. However, on the relationship between creation and salvation the positions of Bavinck and Barth are hardly compatible. This intrigued me. Since Jonker was a student of GC Berkouwer who surely influenced his reading of both Bavinck and Barth, I realised I had to go back to Berkouwer's assessment of Barth and discovered that he remained very critical of Barth on this point, also in his The Triumph of Grace in the Theology of Karl Barth (see Berkouwer 1956, also Conradie 2011:96-98).

In subsequent work on theological reflections on creation and salvation in the South African context, with specific reference to the town of Stellenbosch, I also read the appropriate sections of Johan Heyns' Dogmatiek (1978:101-103). ${ }^{2}$ It was clear to me that this was nothing but a defence of Bavinck's approach explicitly distancing himself from Barth on this point. I therefore recognised that in my appreciation of Bavinck I was also aligning myself more closely

1 Ernst M. Conradie is Professor in the Department of Religion and Theology at the University of the Western Cape.

2 For a discussion, see Conradie, \& Pauw 2011. 
with Heyns than what I may have thought. This made me uneasy for I also read Ntoane's (1983) critical assessment of Heyns' form of Calvinism. ${ }^{3}$ I knew that at least the early Heyns was deeply influenced by the philosophy of Dooyeweerd - a scholar often quoted in circles that defended apartheid theology. Moreover, Heyns studied under HG Stoker whose notion of creation ordinances was widely used in legitimising apartheid. These considerations obliged me to investigate Heyns' approach in more detail. What are the similarities and differences in the ways Heyns and Jonker read Bavinck? I need to admit here that I was never attracted to Heyns' theology. I found his style of writing arid and uninteresting since he seemed (at least to me as a student) to have more answers than questions. For that reason it came as a bit of a shock to me to discover more similarities in terms of thematic interests and positions adopted than I expected. ${ }^{4}$ I also need to acknowledge that I never met Heyns in person and never attended conferences or lectures that he addressed, except for a session (on the document Church and Society) of the 1986 General Synod of the Dutch Reformed Church that I attended and which Heyns chaired. In what follows below I may therefore have missed aspects of his life and work that others would immediately recognise.

In this contribution I wish to offer a distinction that may help to assess Heyns' position, namely between sitting at Bavinck's left hand and sitting at his right hand. In the next section I will clarify this distinction in terms of an emphasis on either the content or the experience of Christian faith. I will then raise the question how Heyns' position in this regard may be interpreted.

\section{BAVINCK'S RIGHT AND LEFT HANDS}

The distinction between Bavinck's left and right hand is best associated with the famous distinction between fides quae creditur and fides qua creditur. Of course, any reformed theologian would insist that what one believes is inseparable from that one believes it. Nevertheless, the one is all too often emphasised more than the other. My suggestion is that an (Christological?) emphasis on fides quae would place one towards Bavinck's right hand while a (Pneumatological?) emphasis on fides qua would place one towards Bavinck's left hand. This distinction is clearly tenuous and calls for further clarification, also because it is influenced by a host of other theological, social and political considerations. It is tempting to make connections with the left and right in terms of political economy or with the kingdom of God's left hand and of his right hand, but I will not seek to develop such a correlation here. I will merely hint as possible leads for further reflection.

What is at stake is the relationship between the reformed orthodoxy of the 17th to the 19th centuries and the reinterpretation of the reformed tradition in the neo-Calvinism of Kuyper, Bavinck and their followers. In the reformed orthodoxy that Bavinck inherited the emphasis was clearly on the cognitive content of the Christian faith. The fresh insights of Calvin's reformation had to be defended against the counter-reformation, the Lutheran reformation and the radical reformation. There was an obvious need to clarify the cognitive content of these insights. This was done in the form of propositional truth claims through a return to 3 Ntoane argues that there are significant differences between Calvin and the theological approaches of FJM Potgieter and JA Heyns, especially in terms of the way in which the created order is introduced. In this way he embraces Calvin's theology as an instrument for the struggle for black liberation, but distances himself from the "Calvinism" which he finds in Potgieter, Heyns and others.

4 One example is Heyns' $(1966,1969,1972)$ early interest in the issue of secularisation. I was not really influenced by these books but certainly grappled with the same issues in my student years. Another example is the interest in intellectual problems around the immortality of the soul (Heyns 1959). 
NGTT: Oopbron - http://ngtt.journals.ac.za

a form of scholasticism by employing Aristotelian categories. ${ }^{5}$ This one-sided emphasis on cognitive content almost necessarily prompted the responses of romanticism, pietism and the so-called ethical direction in Dutch theology.

Bavinck's way of steering between these influences was shaped by three significant insights. ${ }^{6}$ Firstly, the impact of the historical awareness of the 19th century on Bavinck and Kuyper is undeniable. While they had reservations about social revolution and evolutionism as a worldview, both recognised the challenge posed by historicity: the Christian faith cannot merely be formulated in abiding propositional truth claims. A recognition of historical change and thus of contextual considerations is both necessary and legitimate, if the God of Christianity is indeed a God of history. ${ }^{7}$ Bavinck and to some extent Kuyper did not deny biological evolution either. ${ }^{8}$ Secondly, this prompted, at least in embryo form, a hermeneutical awareness. How should the Christian faith be reinterpreted in changing circumstances? How should a literal interpretation of the Bible be assessed? This prompted the famous suggestion of an "organic" rather than a "mechanic" notion of the inspiration of Scripture (Bavinck 2003: 387-448). Thirdly, one may say that the central insight of Kuyper and Bavinck was to clarify the kind of knowledge that "saving faith" entails. ${ }^{9}$ Bavinck (2003:613) observes that orthodoxy ended up in rationalism on the one hand and pietism on the other: "Doctrine and life increasingly distanced themselves from each other. Head and heart vied for priority." By returning to Calvin he was able to recognise that such knowledge is best understood as analogous to knowledge of a person, namely God in Jesus Christ, and not merely as propositional statements and intellectual assent to such statements. ${ }^{10}$ Of course knowledge of a person has some cognitive content otherwise it would be empty. It entails both knowledge (cognitio) and trust (fiducia) as the work of the Spirit in us. For Bavinck, there is no necessary tension between faith, knowledge, science and rationality (or between nature and grace). Faith entails knowledge and comprehension, but yields in the end wonder, admiration and adoration (Bavinck 2003:619, 621). ${ }^{11}$ Such personal knowledge is also dynamic. It has to be

5 Admittedly, Bavinck was still deeply influenced by the neo-Thomistic notions ideas, substance and attributes. For a discussion, see Bremmer (19961:313-343).

6 The most detailed discussion in this regard may be found in the doctoral dissertations by Bremmer (1968), Veenhof (1968) and Van Keulen (2003).

7 Bremmer (1968:316) suggests that Bavinck was one of the first reformed theologians that recognised the significance of the history of revelation in the light of the historical consciousness that emerged in the $19^{\text {th }}$ century. Bavinck interpreted God's special revelation soteriologically by focusing on how God engaged with humanity in order to renew the entire cosmos.

8 In a long essay on evolution Kuyper (in Bratt 1998:403-440) focuses on the philosophical assumptions of evolution as an approach to science and as a worldview ("evolutionism" one may suggest). His argument seems to be that evolutionary theories have failed to see the proper coherence, the systematic unity of things and have offered a rival view of the origin, coherence and destiny of the world. However, he did not reject the scientific data collected by evolutionary scientists out of hand and was not necessarily opposed to the idea that one species may have evolved from another. Unlike some of his neo-Calvinist followers, Kuyper's understanding of God's work of creation remained dynamic, prone to historical progression and organic growth through "development" along the line of God's ordinances.

9 Bavinck (2003:497-622) discusses this with considerable erudition in his Reformed Dogmatics in critical altercation with Scholasticism and liberal theology after Schleiermacher.

10 Bavinck (2003:573) says: "This much is certain: faith in Reformation theology was not a matter of knowing a number of doctrinal truths but consisted in the soul's union with the person of Christ according to the Scriptures and with Scripture as the word of Christ." See also the discussion in Rossouw (1963:157-158).

11 For a discussion of this doxological element in the knowledge that faith involves, see also Rossouw (1973). 
refreshed on a daily basis, in the case of knowledge of God through reading the Bible and through prayer. It has to be every morning new. ${ }^{12}$

These three insights signalled a move away from reformed orthodoxy, albeit that this shift remained tentative and not always clear, for example as far as a hermeneutical awareness is concerned. Bavinck never really broke with a somewhat literal reading of the Bible, one may say especially in his protology and eschatology. Here one continues to wonder how the last decade of his life should be interpreted. ${ }^{13}$ Why did he shift his attention towards ethics and the social sciences? He was evidently uneasy about the plausibility of his own approach, but what was he concerned about? My guess is that this had everything to do with his biblical hermeneutics. ${ }^{14}$ An interesting anecdote is that his widow apparently joined the breakaway church of Geelkerken in 1924, following the controversy over whether the snake really spoke in the Garden of Eden. Either way, Bavinck's unease and timidity remains the subject of much conjecture. In a telling booklet based on archival material Kees van der Kooi and others express the wish that Bavinck would for once convey his true colours. ${ }^{15}$

My observation is that this tentative shift away from reformed orthodoxy, signalled by the term "neo-Calvinism", remained open for interpretation after Bavinck's death. In the 1920s and 1930s this allowed for the predominance of those sitting on Bavinck's right hand. This is signalled by the so-called apologetic approach to theology of Valentijn Hepp, Bavinck's successor in the systematic theology chair at the Free University in Amsterdam. Hepp (1921) wrote a significant early biography on Bavinck. It should also be noted that Hepp influenced F. J. M. Potgieter who studied under him and used his material in teaching theology to students at Stellenbosch University. ${ }^{16}$ More significant is the school of philosophy associated with Herman Dooyeweerd and D. Th. Vollenhoven. Here one finds an attempt to operationalise the core insights of Kuyper and Bavinck on the transformative influence of Christianity in society.

12 Admittedly, this insight came to fuller fruition only later, namely in Berkouwer's theology (see below).

In fact, Berkouwer resisted the notion that Kuyper and Bavinck, and before them Calvin had captured the meaning of Scripture. He draws on Bavinck to insist that the Christian confession is not to be reduced to a deadly orthodoxy. Berkouwer argues that dogmatics cannot be developed towards a system of truths in any objectifying or rationalist way, precisely since it is born from knowledge of God coram deo. Jonker suggests that Berkouwer's entire theology may be regarded as an attempt move away from such scholastic elements in the reformed tradition in which he stood. He also moved away from Bavinck's recognition of the possibility of natural theology. See especially Jonker (1973:91, 93, 101, 103).

13 After completing a second edition of his Reformed Dogmatics (only adding some new literature to the first edition) in 1911, Bavinck did very little further work in dogmatics. He also sold a collection of his books in dogmatics, especially from the period of the reformed orthodoxy. He added in a comment to Hepp "I am not working on that any longer". See Bremmer (1966:249).

14 According to Bremmer (1966: 263-266), Bavinck discussed matters relating the inspiration and authority of Scripture with students and participated in discussion on that at the synod of Leeuwaarden in 1920.

15 The shift in Bavinck's theology in the last decade or so of his life forms the subject of much interest. As Berkhof $(1989: 114,133)$ observes, Bavinck probably recognised that modernity required a much more vigorous renewal of theology, even compared, perhaps, to what his own approach allowed. In particular, the issues arising from the historical-critical reading of Scripture required a different approach. Was he sensing that his own direction is heading towards a dead end (as Berkhof wonders)? Was he struggling to shake off the burden of reformed Scholasticism and its emphasis on faith as intellectual assent? The test case may well be Bavinck's views on the authority of Scripture, since some of his former students began to question a quasi-literal reading of Scripture. An interesting account of this is given in a booklet entitled "If only Bavinck would reveal his true colours" (Harinck, Van der Kooi \& Vree 1994). For a detailed discussion, see Van Keulen (2003:68-225).

16 This information is based on oral communication from Prof Vincent Brummer and Dr Murray Coetzee, students at Stellenbosch in the 1950s and 1970s respectively. 
NGTT: Oopbron - http://ngtt.journals.ac.za

The Christian faith does not allow separation from society; Christ's reign had to be established in every square inch of society. Dooyeweerd's writings tend to become more a-historical than that of his predecessors. The attempt is to formulate, rather precisely, a number of abiding principles for the structuring of society. Dooyeweerd (1935-1936) described these principles in terms of his "wysbegeerte van de wetsidee" (ideas of law), while H. G. Stoker developed this into a philosophy of the "skeppingsidee" (creational ideas). Stoker's concepts provided the intellectual tools employed in apartheid theology to introduce race as one of the so-called "orders of creation" that God intended from the beginning. The diversity of races therefore had to be maintained, if necessary through law and order.17

One may argue that G. C. Berkouwer positioned himself more to the left of Bavinck than to the right on this point. In his books on faith and justification (1954), and faith and sanctification (1952), especially, he introduced the notion of correlation to indicate the tension between what Christ has accomplished and the work of the Holy Spirit in and through us. He thus recognised the need for an appropriation of salvation through a life of faith. This implies a thoroughly hermeneutical notion of doing theology. He interpreted that in existentialist categories 18 but resisted the more radical emphasis of Bultmann and others on faith as human self-actualisation. For Berkouwer, the focus remained on what is being appropriated (fides quae), namely salvation in Christ. With his notion (not method) of correlation he resisted both the objectifying tendency that he found in protestant scholasticism 19 and the subjectifying tendency in liberal theology since Schleiermacher (according to Jonker 1973:105). One may therefore say that Bavinck's incipient historical and hermeneutical awareness comes to fuller fruition in Berkouwer's theology, but then a form of hermeneutics following the axiom of Sacra Scriptura sui ipsius interpres (Jonker 1973:106). It may be noted in passing that Berkouwer was apparently an early critic of apartheid policies in South Africa.

Berkouwer's position may be clarified in terms of his many conversations with the theology of Karl Barth. In the context of the heated discussions between neo-Calvinists and Barthians in the Netherlands, Berkouwer's early review of Barth's theology in Geloof en Openbaring in de Nieuwere Duitsche Theologie (1932) is quite interesting. Here he argues that Barth's radical emphasis on the subjectivity of God and his rejection of any form of continuity between God and humanity leads to the affirmation that God can only be known by Godself. Berkouwer (1932:212) wonders whether Barth can account for the impact of salvation on God's own creation. Does any focus on that which is creaturely necessarily jeopardise the sovereignty of God? There is a need, he says, for a correlation between revelation and faith in which faith is not seen as something that leaves the created reality untouched. Berkouwer criticises Barth's actualistic understanding of faith on the basis of his conviction that faith is to be understood within the tension between creation and re-creation. For Berkouwer creation may be distinguished from God, has an integrity of its own, and yet remains dependent on God.

17 For a discussion of Stoker's role in the development of apartheid theology, see Coetzee (2011:179-195). 18 See the discussion by Jonker (1973:107-109). Berkouwer was criticised (e.g. by Berkhof) for reducing the cosmic and societal scope of the gospel to the salvation of the individual and describing that in pietist and existentialist terminology. Jonker defends Berkouwer on this point, notes that the crucial role of faith also as far as the cosmic scope of God's work is concerned, but acknowledges that Berkouwer at times left room for a misinterpretation of his position. He questions the clarity of Berkouwer's notion of reason, verification and empirical data.

19 In the first paragraph of a contribution to a Festschrift for Berkouwer, Jonker (1973:86) notes as features of Berkouwer's theology his existential, non-speculative and biblically orientated dogmatics. He adds that this approach enabled Berkouwer to resist the threats of scholasticism in the ecclesial context where he was situated, in my terminology the neo-Calvinists sitting on Bavinck's right hand. 
God's revelation touches creation in the form of faith. The underlying problem, Berkouwer argues, is Barth's emphasis on act instead of being. He asks whether one can still speak of the real existence of creation (creatura) or whether this would necessarily jeopardise an actualistic understanding of God's work (Berkouwer 1932:212, also Brinkman 1983:35-42). Brinkman (1983:66) captures Berkouwer's early critique of Barth in this way: "According to Berkouwer, for Barth there could be no possibility that God's grace would transform the relationships that were created. Grace does not actually restore life but stands outside of it. Faith remains alien to life" (my translation). Here Berkouwer is clearly in continuity with Kuyper and Bavinck, his neo-Calvinist teachers, yet his engagement with Barth's actualistic approach position himself on Bavinck's left rather than his right. Barth himself was at times appreciate of Bavinck, for example on God's incomprehensibility (see Barth 1957:186), but was no follower and therefore cannot be positioned on Bavinck left but certainly also not on his right.

One may observe that Van Ruler's position is in this respect very close to that of Berkouwer. There can be little doubt that his creation-centred theology follows and remains closely aligned to that of Bavinck and entailed an eschatological radicalisation of Bavinck notion of re-creation. ${ }^{20} \mathrm{He}$ developed a more independent pneumatology and could on this basis recognise the need for an appropriation of salvation in church and society. Where Berkouwer used the notion of "correlation", Van Ruler (see 2011:445-446, Van Keulen 2010) proposed the concept of a "theonomous reciprocity". His emphasis on history is certainly more strongly developed than that of Bavinck. Curiously, Van Ruler showed considerably appreciation for reformed orthodoxy and took comments on the underlying scholasticism of his thought as a compliment. ${ }^{21}$ Van Ruler wrote a lot about politics, also on the concept of justice (see 1978:159173), but his own political views (proposing a form of meritocracy) should be regarded as being on the right rather than the left of the spectrum.

In the Dutch context I would say that Kuitert may be sitting far to the left of Bavinck, while still standing in the same tradition. This may be difficult to demonstrate given diachronic developments in Kuitert's oeuvre. In his early work Kuitert $(1966,1974,1977)$ wrote extensively on the reality of faith (with an emphasis on fides qua) but not in pietistic or existentialist terms. In his later work he is quite far removed from reformed orthodoxy in the sense that there is little emphasis on a more or less orthodox notion of fides quae. ${ }^{22}$

In the South African context one may argue that a new generation of theologians who studied at the Free University in the 1950s and 1960s intuitively recognised that apartheid theology involved a return to "the old paths" of reformed orthodoxy, thus sitting on Bavinck's right hand. ${ }^{23}$ Apartheid theology could therefore only be resisted through a new methodological orientation. Here I would mention the contributions of Jaap Durand who recognised the

20 Dirk van Keulen (the editor of Van Ruler's Verzameld Werk) puts this strongly: "In my view, the main line of Van Ruler's theology can be read as a radicalised reception of Bavinck's central thought that 'grace does not abolish nature, but affirms and restores it'." See Van Keulen (2011:206).

21 Van Ruler was highly appreciative of reformed orthodoxy and even regarded it as the "ripest form of theology", one that "truly investigates questions with finesse". See Berkouwer \& Van der Woude 1969:17). Nevertheless, he integrated the insights of reformed orthodoxy and reformed pietism (Nadere Reformatie) with extensive writings on bevindelijkheid and his notion of "theonomous reciprocity".

22 This is signalled especially by Kuitert (1992). Bavinck certainly dealt with the same kind of issues but would not have given such a title to a book.

23 This is evident from the struggle of the "Oupajane" (going back to the old paths) against Professor Johannes du Plessis. For a recent discussion, see Coetzee (2011:168-179). 
NGTT: Oopbron - http://ngtt.journals.ac.za

historicity of theological reflection with increasing clarity, ${ }^{24}$ of Willie Jonker who developed a more hermeneutical form of theology as listening to the living Word of God through scriptural exegesis, ${ }^{25}$ and of Hennie Rossouw who recognised the need to clarify the philosophical assumptions of theological hermeneutics (see already 1963). How, then, did Johan Heyns position himself in this context? What was the influence of Berkouwer (under whom Heyns did his first doctorate) on Heyns' reception of Bavinck?

\section{WHERE DID JOHAN HEYNS SIT?}

Throughout his extensive oeuvre it is obvious that Heyns regarded himself as following in the footsteps of Herman Bavinck. He affirms Bavinck's position on grace restoring nature. Salvation as re-creation affirms God's work in creation. ${ }^{26}$ His theology may be regarded as an attempt to translate the central insights of Bavinck into a theology of the kingdom of God - which suggests a more eschatological orientation to his theology compared to that of Bavinck. God's work in history moves from proton to eschaton in order to reach the destiny of creation, namely the reign of God. This emphasis on God's reign in Heyns' theology is beyond dispute (see Heyns s.a. 66-68, 74, 1994; Van der Watt 1988:3). It is also clear that he sought, with Bavinck, to keep together faith and reason, general and special revelation, ${ }^{27}$ science and theology, creation and salvation. Like Bavinck, he did so in conversation with views in philosophy and the various sciences. The more pertinent question is to what extent he remained true to his training in neo-Calvinist philosophy in his formative years (he did his first degree at Potchefstroom and obtained a second doctorate in philosophy under HG Stoker ${ }^{28}$ ). On which side of Bavinck did Heyns position himself? ${ }^{29}$

The best way of identifying the influence of neo-Calvinist philosophy may be through his contributions to a volume entitled Op Weg met die Teologie (1974), which he co-authored with Willie Jonker. In an intriguing introductory note the two authors (1974:11) indicate that they trust that the similarities between their positions would be so evident than the smaller differences between them that may be there would not bother the reader. ${ }^{30}$ Of course, such

24 For a detailed analysis of Durand's writings, see especially Smit (2009:131-167).

25 One example is Jonker's Die Woord as Opdrag (1976) where his underlying approach becomes evident.

Theology entails listening to the Word of God through exegesis and through the illumination of the Holy

Spirit. Preaching expresses this Word anew ("naspreke").

26 In his Dogmatiek Heyns (1978:103) offers a critique of the direction introduced by Barth, namely where creation is regarded as the external basis for the covenant and where God created with a view to the incarnation of the Son. He does so by reiterating Bavinck's notion of grace restoring nature. Without the historical order of creation and salvation the meaning of both would be lost.

27 On the distinction between special and general revelation (in nature, history and human conscience), Heyns stays very close to Bavinck. See Heyns \& Jonker (1974:154f). He does engage in polemics with Barth on this point and argues that Barth's denial of general revelation would lead to the isolation of theology from other disciplines and to a complete secular approach to science (p. 156-157). However Heyns also criticises any form of natural theology for an independent interest in general revelation. He insists that general revelation should be understood in terms of special revelation (p. 159). See also Heyns (1978:7-11).

28 In a biographic essay included in a Festschrift for Heyns, PB van der Watt (1988:2) observes that some would say that no one had a greater influence on Heyns than this Calvinist thinker.

29 One may also explore a related question, namely on the way in which Heyns responded to Karl Barth's theology. He wrote his first dissertation on Barth's anthropology (see 1964) and wrote several further articles on Barth. The diverging ways in which Jonker and Heyns interpreted Barth may be a themes worth exploring in a doctoral dissertation!

30 In an excellent article 20 years later Jonker (1994) offers a critical appraisal of Heyns' theology of the 
a comment raises one's curiosity and would tend to have the opposite effect than the one intended. Was Heyns perhaps sitting at Bavinck's right hand and Jonker at Bavinck's left hand?

The first chapter of this volume, written by Heyns, offers a philosophy of science that would be congenial to theological reflection on the revelation of God. This Heyns finds in the school of reformed philosophy associated with Dooyeweerd and others. It is interesting to note several positive references to Stoker and the many inclusions of Stoker's works in the lists of literature provided at the end of each section. ${ }^{31}$

In a telling section on the sources of science he offers a small dogmatics in five steps: a) God and cosmos has to be distinguished and nothing in the cosmos may be absolutised; b) God is the Creator of everything in the cosmos and also the diversity in the cosmos (an emphasis typical of apartheid theology); c) God embedded cosmic laws in the created order that may be studied by the sciences; d) Sin has entered creation, also affecting nature; e) Through God's general grace the destructive impact of sin is curtailed, thus making room for God's special grace, God's work of re-creation (in Heyns \& Jonker 1974:33-35). The continuity with Bavinck, Dooyeweerd and Stoker is evident. The ease with which Heyns seems to know what God created, as indicated in the second step, may be noted. Although the impact of sin is recognised, it is taken for granted that one can study the laws of nature (alongside Scripture) and the diversity in the world as God-given and indeed as God's creation. There seems to be little recognition of cosmic, biological or human evolution. Evolutionism is explicitly denied on the basis of step one, namely the absolutising of the process of evolution. ${ }^{32}$

In the second chapter Heyns explores various aspects of theology as science. ${ }^{33} \mathrm{He}$ distinguishes between pre-theological reflection on a life of faith and theology as a more disciplined, systematic and indeed scientific reflection on the cognitive content of faith. He refers to the distinction between fides quae and fides qua and suggests that the emphasis in a life of faith is on fides qua while the emphasis in theological reflection is on fides quae. The theologian seeks to understand what it is that is believed (fides quae) in order to come to a deeper faith (Heyns \& Jonker 1974:130, Heyns 1978:13). Theology offers systematic responses to the Word of God by him (Heyns uses only male pronouns) who has been addressed by God (Heyns \& Jonker 1974:130). It is clear that Heyns does not want to separate theological reflection from pretheological reflection. Theological reflection participates in the motto credo ut intelligam. Faith is a necessary precondition for theology in order to recognise God's revelation as revelation

kingdom of God where his appreciation for Heyns is evident, but also the significant differences between them. These differences are related to the influence of Stoker on Heyns and more specifically his theology of restoration. The kingdom of God is indeed understood as God's destiny for creation which is realised through obedience to God's law. However, this is understood in terms of the restoration of God's will for creation - which, for Heyns, may be understood in terms of Stoker's category of "skeppingsidees". Stoker's categories thus restrains Heyns' understanding of God's will, allows for a strong emphasis on God's general revelation in nature and history (providence) and inhibits (but does not mute) his prophetic critique against the status quo in church and society during the 1960s and 1970s.

31 Heyns describes Stoker as doing ground breaking work in the field of philosophy of science (in Heyns \& Jonker 1974:18, 51-58). It is interesting to note that there are also numerous references to Hennie Rossouw's dissertation, Klaarheid en Interpretasie (1963).

32 In a document on evolution Heyns (no date) distinguishes between evolution as theory (based on natural selection) and evolutionism as an extrapolation of the theory towards a comprehensive worldview. He argues against both, namely on the basis of insufficient evidence for the theory and on the basis of the atheist assumptions of the worldview. Of course this does not imply that Heyns denied the evolution of species as a fact of history.

33 For a critical discussion, see Wethmar (1994). 
NGTT: Oopbron - http://ngtt.journals.ac.za

(Heyns \& Jonker 1974:182). For Heyns (1992:14-15) faith is indeed a form of knowledge, namely knowledge of God embedded in a personal relationship governed by prayer, although he is quick to add that it is, more precisely knowledge of God's revelation since we do not have direct access to God (Heyns \& Jonker 1974:150-163). He then adds that Christians are not called to believe in their faith, but in the content of their faith. The focus of theology is not on the fact that people believe but on what they believe (Heyns \& Jonker 1974:184-185). One if left with the impression that Heyns formally acknowledges the distinction between fides qua and fides quae but that his main emphasis in on the fides quae.34 This allows him to also emphasise that theological reflection is theoretical and systematising, critical and verifying (see Heyns \& Jonker 1974:131, also Heyns 1992:26-30). He boldly offers a definition of theology: "Theology is the scientific, time-bound response to God's revelation of Himself and His direct relationship with the cosmos" (in Heyns \& Jonker 1974:137, my translation).

It would therefore be unfair to suggest that Heyns returns to a form of reformed orthodoxy. He emphasises the dynamic nature of theological reflection - as an obedient response to an ongoing process of listening to God's Word. He recognises the contextuality of theological reflection and the inevitability of historical changes in the content of theological responses (see Heyns \& Jonker 1974:132-133, 148-149). ${ }^{35}$ A response to the message of God's revelation has to be formulated anew in changing cultural and historical situations by studying the dynamics of a particular context. It is therefore time-bound as a response in and for a particular time (in Heyns \& Jonker 1974:218-228). In many of his publications Heyns develops this in terms of a theology of obedience to God's will. God rules (regeer) and humans respond (reageer) (see Heyns 1973:81). Heyns also recognises that this obedient response involves a Christianising of culture, a sense of responsibility towards science and an engagement with that which is natural in order to establish signs of the coming reign of God on earth. This not only entails a correlation between revelation and faith (as Berkouwer maintained), but also an analysis of the contemporary situation (Heyns 1973:75). He recognises that such a notion of contemporary theology implies the problem of continuity: How can theology be contemporary and remain theology? How can theology remain theology and be contemporary? Heyns answer this question through a theology of obedience to God's will.

How God's will is to be determined requires further clarification (see below) but at least it is clear that the categories of "response" and "obedience" does not imply a mere return to reformed orthodoxy. Theology is the fallible work of humans, dynamic, provisional, fragmentary and historical (see Heyns \& Jonker 1974:135, 186; Heyns 1973:81). Obedience is not only opposed to disobedience but also to a mere repetition of previous forms of obedience (Heyns 1973:82). Nevertheless, Heyns places considerable emphasis on the need for systematic reflection and on the scientific nature of the discipline in order to yield knowledge and insight that would be verified, valid and reliable. Heyns concludes:

It is faith in the heart of a theologian that makes theology possible and keeps it alive, but it is faith in its directedness to revelation that ensures the direction of theology and that guarantees its identity (in Heyns \& Jonker 1974:186).

34 Nevertheless, Heyns (in Heyns \& Jonker 1974:185) can write eloquently about faith as the only access to the object of theological studies, namely the revelation of God: "Faith is our yes in response to God's Word, our amen to His promises, our yielding to His love, our reaction, through the work of the Holy Spirit, to His act of grace in Jesus Christ" (my translation).

35 Jonker (1994:15-16) suggests that Heyns" emphasis on the categories of "response" and "obedience" is in line with Berkouwer's notion of correlation and ensures the dynamic nature and ethical appeal of his theology. 
On the basis of the observations above I would suggest that the approach that Heyns followed on the relation between fides qua and fides quae would position him neither on Bavinck's left or right. If anything, there is a stronger emphasis in Heyns on the historical situatedness of theological reflection and on the hermeneutic task of theology than in Bavinck. In a Festschrift for Jonker, Heyns (1989:5-6) emphasises that theology offers a verbal response to God's Word, that symbolic language is required for this response and that this response is situated in a particular context. ${ }^{36}$ Compared with Jonker there is in Heyns' writings neither more nor less emphasis on doctrine or on the binding of theology to ecclesial confessions, ${ }^{37}$ although there is certainly more of an emphasis on identifying underlying doctrinal systems (Heyns 1992:3334). Heyns warns against building elaborate doctrinal systems but suggest that the task of dogmatics may include highlighting underlying systems and emerging patterns in God's revelation. Admittedly, there is a tendency in his work and in his style of writing to engage in multiple, almost scholastic distinctions and to emphasise the scientific nature of theological reflection. He is in search of intellectual clarity and not only confessional fidelity. This is balanced by his critical engagement with the challenges of his time with specific reference to secularisation that he already addressed in the 1960s and apartheid in South Africa in the 1970 s and 1980s (see below). Although he takes up such challenges, he tends to follow an apologetic approach by defending the reformed theology that he learned from Bavinck.

Given the theological tradition in which Heyns stands and his professional engagement in academic excellence, the emphasis that Heyns placed on theology as a disciplined and systematic form of inquiry (he would say theology as a science) cannot be faulted. However, the particular set of conceptual categories that he employed in his views on science and philosophy in relation to theology seems to have restrained his theology. Indeed, he remained true to his formative training in the philosophy of Dooyeweerd, Vollenhoven and Stoker. While he evidently read works by scholars engaging in the "new hermeneutics" (of Bultmann, Ebeling and Fuchs), he rarely employs the analytic tools of hermeneutical philosophy and indeed warns against the tendency to absolve theology into hermeneutics (see Heyns s.a.:65).

One may argue that Heyns addressed historic challenges through a set of rather a-historic conceptual tools. The philosophy of science that he employed did not enable him to recognise the significance of what may now be described as "the story of the universe" in which the socalled "laws of nature" are themselves telling a story rather than an order that God inscribed in nature "in the beginning". Although Heyns is fully aware of the dangers of natural theology and recognises the impact of sin, he too readily identifies God's creation with nature as we know it. While apartheid theology emphasised that God's work of re-creation is aimed at restoring the order (creation ordinances) that God established in the beginning and that was disturbed by sin (imposing unity on God-given diversity), Heyns recognised the eschatological significance of re-creation through his use of the category of the kingdom of God. Nevertheless, he tends to understand the reign of God in terms of the restoration of God's foundational plan for creation. Heyns (1994:9) says: "The laws that God himself as Creator and Provider laid down in the creaturely reality, must be discovered, formulated and obeyed by humans through their cultural engagement" (my translation). He does not speak of creation ordinances but 36 I must admit that Heyns' style of making conceptual distinctions still leaves me confused as to how he

sees the task of dogmatics. Is the task of dogmatics a heuristic one, namely to capture the biblical message and to express this message systematically in and for a particular context (see Heyns 1989:9)? Or is its task to reflect critically on the response of the church to that message in terms of the confessions of the church and its attempts to capture the content of the faith in doctrinal formulas or guidelines (1989:8). Or is it perhaps to offer such response constructively?

37 See the section by Jonker on ecclesial confessions in Heyns \& Jonker (1974:200-217). 
NGTT: Oopbron - http://ngtt.journals.ac.za

nevertheless suggests that these "societal associations" (samelewingsverbande) are based on the basic plan (grondplan) that the Creator embedded in creation. This plan has normative status. Moreover, this plan precedes the act of creation. The epistemological problem as to how such a plan can be known given the impact of sin and cosmic and biological evolution is simply not addressed.

The underlying problem, as recognised by Willie Jonker, Heyns's lifelong friend and colleague, is that this allegiance to Stoker's categories curtails the critical edge of Heyns' position. According to Jonker, Heyns' theology is descriptive, offers a cosmological vision and tends to become a theologia gloriae (perhaps against Heyns' intentions) that does not taken the broken and demonic reality (in South Africa) seriously enough. There are always already revealed answers available to every problem in society. Jonker (1994:19-20) refers to the critique of Noordmans on the cultural theology of Schilder and other neo-Calvinists that departs from creation and culture and then adds:

The emphasis is thus not on sin and guilt, but on the restoration of creation and the development of culture. The actual salvific events witnessed in Scripture are then regarded as a means to the goal of allowing the powers embedded in creation, that were repressed through sin, to awaken and to develop according to their original createdness. Thus the focus is shifted from the cross to creation. This can easily lead to a situation where a cultural-philosophical vision replaces the gospel or redemption. This critique does not necessarily apply to Heyns. However, his departure from [the category of] creation does lead to an under-emphasis on the abyss of sin and evil in the light of the sunny, clear and positive vision that he treasures.

\section{Conclusion}

On the basis of the preceding observations, I may offer two concluding statements:

Firstly, one cannot easily position Heyns on either Bavinck's left or right hand as far as a movement away from reformed orthodoxy is concerned. Compared to South African colleagues such as Willie Jonker, Heyns certainly places more emphasis on the systematic ordering of theological themes and more readily engages in scholastic distinctions on a host of issues. His style of writing is one of offering an apology for a particular reformed understanding of the Christian faith in response to contemporary challenges (including that of secularism). For every theological question he seems to have a ready answer.

Secondly, Heyns often uses neo-Calvinistic categories derived from Dooyeweerd and Stoker in his philosophy of science and in his social analysis, although he does not draw on the notion of creation ordinances all that much. This seems to restrain the way he utilises the theological categories that he derives from Bavinck (grace restoring nature) and also his notion of what restorative justice entails. Moreover it inhibits his contextual analysis.

\section{BIBLIOGRAPHY}

Barth, K 1957. Church Dogmatics, Volume Il, The Doctrine of God, Part 1. Edinburgh:T \& T Clark. Bavinck, H 1909. The Philosophy of Revelation. London: Longmans, Green \& Co.

Bavinck, H 2003. Reformed Dogmatics, Volume 1: Prolegomena, Grand Rapids: Baker Academic.

Berkhof, H 1989. Two Hundred Years of Theology: Report of a Personal Journey. Grand Rapids: WB Eerdmans. Berkouwer, GC \& Van der Woude, AS (reds) 1969. In Gesprek met Van Ruler, Nijkerk: GF Callenbach. 
Berkouwer, GC 1932. Geloof en Openbaring in de Nieuwere Duitsche Theologie, Utrecht: Kemmink en Zoon. Berkouwer, GC 1952. Faith and Sanctification. Grand Rapids: WB Eerdmans.

Berkouwer, GC 1954. Faith and Justification. Grand Rapids: WB Eerdmans.

Berkouwer, GC 1956. The Triumph of Grace in the Theology of Karl Barth. Grand Rapids: WB Eerdmans.

Bratt, JD (ed) 1998. Abraham Kuyper: A Centennial Reader. Grand Rapids: Eerdmans.

Bremmer, RH 1961. Herman Bavinck als Dogmaticus. Kampen: JH Kok.

Bremmer, RH 1966. Herman Bavinck en zijn Tijdgenoten. Kampen: JH Kok.

Brinkman, ME 1983. De Theologie van Karl Barth:Dynamiet of Dynamo voor Christelijk Handelen: De Politieke en Theologische Kontroverse tussen Nederlandse Barthianen en Neocalvinisten. Baarn: Ten Have.

Coetzee, MH 2011. Die "Kritiese Stem" teen Apartheidsteologie in die Ned Geref Kerk (1905-1974: 'n Analise van die Bydraes van Ben Marais en Beyers Naudé. Wellington: Bybel-Media.

Conradie, EM \& Pauw, JC 2011. The ebb and flow of creation theology at Stellenbosch University: A story in six chapters. In: Van den Borght, EAJG. \& Van Geest, P (eds): Strangers and Pilgrims: On the Meaning of the Theological Oeuvre of Abraham van de Beek, 739-759. Leiden: Brill.

Conradie, EM 2011. Abraham Kuyper's Legacy for Contemporary Ecotheology: Some Reflections from within the South African Context. In: Conradie, EM (ed.): Creation and Salvation:Dialogue on Abraham Kuyper's Legacy for Contemporary Ecotheology, 3-146. Leiden: Brill Publishers.

Dooyeweerd, H 1935-1936. De Wijsbegeerte der Wetsidee. Amsterdam: HJ Paris.

Harinck, G, Van der Kooi, C \& Vree, J 1994. "Als Bavinck nu maar eens Kleur Bekende": Aantekeningen van H. Bavinck over de Saak-Netelenbos, het Schiftgezag en die Situatie van de Gereformeerde Kerken (November 1919). Amsterdam: VU Uitgeverij.

Hepp, V 1921. Dr Herman Bavinck. Amsterdam: Ten Have.

Heyns, JA \& Jonker, WD 1974. Op Weg met die Teologie. Pretoria: NG Kerkboekhandel.

Heyns, JA 1959. Die Onsterflikheid van die Siel: Enkele Beskouinge. Kaapstad / Pretoria: N.G. Kerk-Uitgewers. Heyns, JA 1964. Die teologiese anthropologie van Karl Barth vanuit wysgerig-antropologiese orienteering. Kaapstad: Tafelberg.

Heyns, JA 1966. Die Evangelie in Krisis. Kaapstad: Tafelberg.

Heyns, JA 1969. Sterwende Christendom? 'n Teologie in die Greep van die Tydsgees. Kaapstad: Tafelberg. Heyns, JA 1972. 'n Teologie van Gehoorsaamheid. Kaapstad: Tafelberg.

Heyns, JA 1973. 'n Teologie van Gehoorsaamheid - Ontwerp van 'n Eietydse Teologie. In: Bakker, JT, Hartveld, JP, Kuitert, HM en Meuleman, GE (eds): Septuagesimo anno - Theologische opstelle aangeboden aan Prof. Dr. GC Berkouwer, 74-85. Kampen: JH Kok.

Heyns, JA 1978. Dogmatiek, Pretoria: N. G. Kerkboekhandel.

Heyns, JA 1981. 'n Teologiese Perspektief. In: Smith, NJ, O'Brien Geldenhuys, FE \& Meiring, PGJ (reds): Storm-kompas. Opstelle op Soek na 'n Suiwer Koers in die Suid-Afrikaanse Konteks van die Jare Tagtig, 15-21. Kaapstad: Tafelberg.

Heyns, JA 1989. "Bybelse" en Dogmatiese Teologie. In: Theron, PF \& Kinghorn, J (reds): Koninkryk, Kerk en Kosmos: Huldingingsbundel ter Ere van Prof W D Jonker, 1-10. Bloemfontein: Pro-Christo.

Heyns, JA 1992. Inleiding tot die Dogmatiek aan die Hand van die Nederlandse Geloofsbelydenis. Pretoria: NG Kerkboekhandel.

Heyns, JA 1994. Die Koninkryk van God - Grondplan van die Bybel. Skrif en Kerk 15:1, 1-12.

Heyns, JA s.a. Die Evolusie-Teorie. Stellenbosch: N.G. Kerkboekhandel.

Heyns, JA s.a.. Die Skrifbeskouing in strukturele perspektief. In: Verhoef, PA, De Villiers, DW \& De Villiers, JL (reds): Sol lustitiae, 65-77. Kaapstad: NG Kerk-Uitgewers.

Jonker, W.D. 1973. Dogmatiek en Heilige Skrif. In: Bakker, JT, Hartveld, JP, Kuitert, HM en Meuleman, GE (eds): Septuagesimo anno - Theologische opstelle aangeboden aan Prof. Dr. GC Berkouwer, 91-103. Kampen: JH Kok.

Jonker, WD 1976. Die Woord as Opdrag: Gedagtes oor die Prediking. Pretoria: NG Kerkboekhandel. Jonker, WD 1994. In gesprek met Johan Heyns. Skrif en Kerk 15:1, 13-26.

Kuitert, HM 1966. De Realiteit van het Geloof: Over de Anti-metafysische Tendens in de Huidige Theologische Ontwikkeling. Kampen: JH Kok.

Kuitert, HM 1974. Zonder Geloof Vaart Niemand Wel: Een Plaatsbepaling van Christendom en Kerk. Baarn: Ten Have. 
NGTT: Oopbron - http://ngtt.journals.ac.za

Kuitert, HM 1977. Wat heet Geloven? Structuur en Herkomst van de Christelijke Geloofsuitspraken. Baarn: Ten Have.

Kuitert, HM 1992. Het Algemeen Betwijfeld Christelijk Geloof. Baarn: Ten Have.

Ntoane, LRL 1983. A Cry for Life: An Interpretation of "Calvinism" and "Calvin". Kampen: Kok.

Rossouw, HW 1963. Klaarheid en interpretasie: enkele probleemhistoriese gesigspunte in verband met die leer van die duidelikheid van die Heilige Skrif. Amsterdam: Jacob van Campen.

Rossouw, HW 1973. Doksologie, ortodoksie, eukumene. In: Bakker, JT, Hartveld, JP, Kuitert, HM \& Meuleman, GE (eds.): Septuagesimo anno - Theologische opstelle aangeboden aan Prof. Dr. GC Berkouwer, 203-212. Kampen: JH Kok.

Smit, DJ 2009. “In die geskiedenis ingegaan". In: Conradie, EM \& Lombard, C (eds): Discerning God's Justice in Church, Society and the Academy: Festschrift for Jaap Durand, 131-167. Stellenbosch: Sun Press.

Van der Watt, PB 1988. Prof. Dr. Johan Adam Heyns - Anno Sexagesimo. In: Wethmar, CJ \& Vos, CJA (eds): ' $n$ Woord op sy Tyd: 'n Teologiese Feesbundel Aangebied aan Professor Johan Heyns ter Herdenking van sy Sestigste Verjaarsdag, 1-8. Pretoria, NG Kerkboekhandel

Van Keulen, DJ 2003. Bijbel en Dogmatiek: Schriftbeschouwing en Schriftgebruik in het Dogmatisch Werk van A. Kuyper, H. Bavinck en G. C. Berkouwer, Kampen: JH Kok.

Van Keulen, DJ 2010. G. C. Berkouwer's Principle of Correlation: An Attempt to Comprehend. Journal of Reformed Theology 4:2, 97-111.

Van Keulen, DJ 2011. Leads for Ecotheology in Arnold A. van Ruler's Work. Conradie, EM (ed): Creation and Salvation: Dialogue on Abraham Kuyper's Legacy for Contemporary Ecotheology, 197-212. Leiden: Brill Publishers.

Van Ruler, AA 1978. Verwachting en Voltooiing: Een Bundel Theologische Opstellen en Voordrachten. Nijkerk: Callenbach.

Van Ruler, AA 2011. Verzameld Werk, Deel IV-A:Christus, de Geest en het Heil (edited by Dirk van Keulen). Zoetermeer: Boekencentrum.

Veenhof, J 1968. Revelatie en Inspiratie: De Openbarings-en Schriftbeschouwing van Herman Bavinck in Vergelijking met die der Ethische Theologie. Amsterdam: Buijten \& Schipperheijn.

Veenhof, J 2006. Nature and Grace in Herman Bavinck (translated by Albert M. Wolters). Sioux Center: Dordt College Press.

Wethmar, CJ 1994. Wetenskaplikheid en Konfessionaliteit van die Teologie: Enkele gesigspunte in verband met die teologiebegrip van JA Heyns. Skrifen Kerk 15:1, 65-74.

\section{KEY WORDS}

Johan Heyns

Herman Bavinck

GC Berkouwer

Willie Jonker

Fides qua

Fides quae

\section{Ernst Conradie}

Department ofReligion and Theology

University of the Western Cape

Private Bag X17

Bellville 7535

econradie@uwc.ac.za 